\title{
Colonial Savages and Heroic Tricksters: Native Americans in the American Tradition
}

\author{
David T. Mitchell \\ Melissa Hearn
}

Near the end of Bernal Diaz's The Conquest of New Spain, he describes the aftermath of Mexico City's destruction by the Spanish Armada. As the battle begins winding down and the once magnificent Aztec center has been razed, Diaz presents an overview of the devastation:

Once the city was free from them (the Aztec survivors) Cortes went out to inspect (the city). We found the houses full of corpses, and some poor Mexicans still in them who could not move away. Their excretions were the sort of filth that thin swine pass which have been fed on nothing but grass. The city looked as if it had been plowed up... There was no fresh water to be found; all of it was brackish.... There had been no live births for a long time, because they had suffered so much from hunger and thirst and continual fighting. (407)

While the Spaniards' destruction serves to underscore their military power, Diaz also makes clear that the annihilation takes place because the Aztec inhabitants refuse to participate in the one necessity of European warfare: the surrender. As the war moves from the outskirts into the city proper, Cortes makes numerous pleas for the inhabitants to acknowledge their defeat and consequent subjugation to the superior military and cultural might of the invader. Yet the "poor Mexicans" never succumb to this imperative to "speak their own enslavement."

Such "stubbornness," as Diaz labels it, leaves the Conquistadors in a military and metaphorical quandary. Either the refusal proves to be the act of a brave and even heroic people or it alludes to the depths of their savagery and foolhardiness. Since to "succeed" in battle depends upon the all-important oral acknowledgment of defeat by the opposition, the Aztecs refuse the Spaniards a sense of completion. Without that literal sign of submission, the situation proves more difficult to categorize than a clear-cut victory or defeat-either Cortes surrenders to the incompleteness of his mission or he removes the evidence of his enemy's resis- 
tance. Either he acknowledges the heroic nature of these people-to die rather than submit-or he destroys them in the midst of their "savagery." Diaz never resolves the question other than to say that residents of the city form their regiments of walking dead and stream out of Tenochtitlan for three days. A "compromise" of sorts is reached where the "survivors" are allowed to remove themselves while leaving behind the evidence of a genocidal ferocity.

This equivocal conclusion to Diaz's book proves instructive for thinking about the ways in which Native Americans have been represented in Colonial histories and literatures since the very beginnings of European contact. The narrative poles of savagery and heroicism that presented themselves to Colonial imaginations infuse the history of American encounters with the Native inhabitants from the fifteenth century to the present.' For the Spaniards, who present themselves as fierce in battle and willing to die for the cause of European "advancement," the Aztecs posed a troubling mirror-image of their own behavior; they, too, proved alarmingly fierce and mortally heroic: "they cared nothing for death in battle" (Diaz 395). This characterization that Diaz deploys more often than not when he refers to the military behavior of Aztec warriors straddles the divide that puzzled Spaniards contemplated when they discussed Native "character." To "care nothing for death in battle" oscillates between a version of "savagery" and a version of "heroicism" that, like the stream of survivors allowed to flee the devastated remains of Tenochtitlan, acts as a metaphorical compromise that contains both possibilities.

The reasons for this duality to Euro-American myths of Native culture and behavior resides in the historical relations between colonizer and colonized. ${ }^{2}$ Unlike Africans who would be uprooted from their homeland in order to be purchased and enslaved on unfamiliar continents, ${ }^{3}$ Native inhabitants of South, Central, and North America would never make practical servants for the invading cultures. In large part, this unsuitability resulted from their utter familiarity with a topography that their European counterparts were struggling to become familiar with themselves. Given that American slavery depended upon the slave's sense of dislocation within the land he or she "works," Native Americans never experienced that prerequisite alienation. Attempts to chain Native Americans to the lands of their ancestral habitation proved impossible. While native peoples could be militarily overcome and forcibly removed from location to location, the Europeans never successfully "displaced" that sense of belonging and intimacy with the land itself.

In this sense, the portrait of Native peoples in U.S. print culture has aspired to exploit a version of heroicism as both a "natural" feature of 
Native American temperament and a longed for ideal of an ever-evolving Euro-American character. As Columbus explained in his "Letter to the Sovereigns," Native peoples serve as a reminder of European man's primitive foundations and as the promise of a return to nature after the fall. ${ }^{4}$ This impulse to catalogue the indigenous peoples of the Americas as the origins of a more sophisticated yet corrupt European civilization, helps to account for the ambivalence of Colonial writers as they approached these New World cultures. Because biblical myth structured their interpretive strategies, European explorers and immigrants viewed the Indian as the symbol of a heroic return to the Garden before the fall and, ironically, as the obstacle to the repossession of that mythical landscape. The negotiation of these antithetical goals left the New World historian and chronicler caught in a curious paradox that required a deft manipulation of language and symbols. The polarities of the hero/savage divide served as the temporary antidote to such a conundrum, and consequently continued to sediment and solidify in the national imagination.

Colonial narratives of Native populations invested in this definitive ambiguity of a people who could be classified in most respects as "conquered," continued to struggle with the resounding absence of their spoken subjugation. Later literary and popular portraits of Native Americans as fiercely heroic and savagely belligerent in their refusal to capitulate would populate the narrow options of a culture that continued to wrestle with the legacy of that adamant refusal. On the shores of Massachusetts Bay, the Puritans would struggle with a similar representational dilemma. Unlike the Spaniards who willingly forged ahead into the unknown territory of a vast empire, the New England immigrants acted in a much more tentative way in their initial contacts and narrative presentations of the "savadge." While Spaniards often caught themselves admiring the military prowess and conceptual strategies of a viable adversary, the English immigrants acknowledged that these native inhabitants proved difficult and untrustworthy representatives of God's will. ${ }^{s}$ Rather than depict them as heroically and strategically defending their own empire, Puritan writers consistently struggled to read God's messages in their competitors' ambiguous activities.

For instance, in one of the best-known tracts of Puritan literature, Mary Rowlandson's captivity narrative straddles the hero/savage opposition that Diaz invokes while relaying a typical portrait of her captors to her contemporary Protestant audience:

The tobacco I quickly gave away; when it was all gone, one asked me to give him a pipe of tobacco, I told him it was all gone; then began he to rant and threaten. I told him when my husband came I would give him some: Hang him 
rogue (says he) I will knock out his brains, if he comes here. And then again, in the same breath they would say, that if there should come an hundred without guns, they would do them no hurt. So unstable and like madmen they were...there was little more trust to them than to the master (the Devil) they served. (352)

For Rowlandson, the "instability" that characterized her Indian captors and allowed them to shift without notice from treachery to kindness reestablishes this quintessential behavioral polarity. Her willingness to leap from an individual exchange to a definition of a population-"like madmen they were"-signals the mythical oppositions that Indians had come to represent in Euro-American letters. Like Diaz, who would simultaneously identify the heroic and the savage inclinations of his military and cultural antagonists, Rowlandson cites the fact of this duality as evidence of an essential demonic nature. She, like other Puritan writers, consistently depicts Indians as the pawns of a Manichean spiritual worldview. Such a representational strategy would keep the Indian eternally oscillating in the popular imagination as the emblem of what was most noble and most corrupt in human nature itself.

Rowlandson's captivity narrative is an important case study in the narrative strategies employed by the early settlers to cope with the internal conflicts they faced in the implementation of a religious utopia. Because the Native inhabitants that existed beyond the parameters of Plymouth Plantation both posed a threat to the fragile colony and acted as a disciplinary device for the reigning magistrates, those colonials held captive like Rowlandson provided an important opportunity. Written under the supervision of religious elites, the survivors of captivity were expected to reassimilate themselves into the spiritual mission of the community by fashioning their stories into examples of individual redemption. The personal intimacy of captivity could only be purged through a fortification of the communal definitions of Indian savagery. In doing so, the now redeemed captive interpreted his/her experience as a gesture of God's benevolence and as an example of the spiritual community's need to reassert its original religious commitment.

As a consequence of this narrative expectation, the Colonial writer's approach to the Indian was a complex portrait of symbolic projections; the figure of the Indian lurked in the shadowy recesses of the world as a mediator between Euro-American phantasms of racial and cultural difference. Captain John Smith's legendary narrative of Pocahontas pivots upon such a colonial fantasy. Rather than cast his narrative net in the direction of the militant figure of the brave, Smith's heroic Indian arrives in the guise of a female princess who intuitively sympathizes with the 
Captain's encroaching victimization. As Smith awaits an opportunity for himself and his men to escape the "treacherous designs" of Powhatan, Pocahontas betrays her father's allegiance and warns Smith and his officers of their impending doom.

Having feasted him [Smith] after their best barbarous manner they could, a long consultation was held, but the conclusion was, two great stones were brought before Powhatan: then as many as could layd hands on him, dragged him to them, and thereon laid his head, and being ready with their clubs, to beate out his braines, Pocahontas the Kings dearest daughter, when no intreaty could prevail, got his head in her armes, and laid her owne upon his to save him from death: whereat the Emperour was contented he should live to make him hatchets, and her bells, beads, and copper. (49)

In a similar vein to Rowlandson and the New England Puritans, the Dutch settlers of Virginia interpret Pocahontas's timely intervention as a strange sign from God. While Native American betrayals were not uncommon - the European colonial expedition in the New World succeeded largely because of rivalries between tribes that the colonizers adeptly exploited - the Pocahontas myth served to fuel European erotic imaginings bound up in the colonial project. Pocahontas's willingness to betray the tribe's plans to bludgeon Smith simultaneously allowed the colonial party to be spared certain death and forwarded Pocahontas as an unexpected vehicle of Indian heroicism.

In Smith's fabled version of her willingness to betray the "treacherous designs" of Powhatan, Pocahontas saves the upper echelon of European military command and thus cements her own centrality within colonial mythology and history. Because the figure of such heroics arrives at Smith's side in the form of an Indian woman, the colonial imagination could assuage itself with visions of being rescued by the erotic symbol of a taboo union. John Rolfe, another Jamestown resident and political figure, later goes on to take Pocahontas as his "squaw," and in doing so symbolically concludes the "final chapter" of European colonization and conquest. Thus the "heroic" act, in the guise of an Indian woman, can be reappropriated into a Euro-American tradition through the narrative restoration of European sexual (and military) prowess.

The mythic plot of Pocahontas would pervade Euro-American literary fantasies for the next two hundred years. While Smith's initial versions of his expeditions in the New World do not mention Pocahontas (she enters into his narrative rendition of the settling of Virginia only in his 1620 edition of New England Trials), her heroic act becomes increasingly expansive as the Captain revised and republished his History. The 
story of his capture and release would evolve from a mere 80 words in The Proceedings, to more than 1,900 words in Book 3 of The Generall Historie.? A parallel expansion of the myth's centrality would occur on the heels of the American Revolution, when the country would begin to look for evidence of its own mythic heroes and origins. During the first half of the 19th century, a popular innovation in genre known as "Indian plays" would assure Pocahontas' place in history through a series of reappropriations and dramatic transformations of Smith's own tale.

From Longfellow's Hiawatha to the assimilated "Indian" love interest in Kevin Costner's Dances with Wolves, ${ }^{8}$ the figure of the tribeswoman torn between divided loyalties has proven to be synonymous with Euro-American fantasies of colonial sympathy and erotic cultural crossings. In the case of Longfellow, who was one of the first EuroAmerican writers to enshrine the figure of the Indian brave in poetic verse, the myth of the domesticated Indian princess serves to highlight the masculine virtues of his hero. In Section 10, "Hiawatha's Wooing," the narrator begins the romance with a dictum about the necessary qualities of generic "woman" transcribed into the "Native American" context of his verse:

As unto the bow the cord is,

So unto the man is woman,

Though she bends him, she obeys him,

Though she draws him, yet she follows, Useless each without the other! (179)

The key metamorphosis that Longfellow achieves in this poem that diverges from a long tradition of American writing on the ambivalent figure of the Indian hero, is that of Hiawatha's Romantic integrity as a full-fledged heroic figure.

Unlike the Conquistador and Puritan versions of the Native American quandary, Longfellow crafts his mythic Indian into a model of physical valor and moral vision. Yet this literary "evolution" occurs in the midst of a gendered sublimation. While Hiawatha serves as a paeon to masculine prowess, Minnehaha, "the lovely Laughing Water," occupies a position that comes equipped with its own built-in ambivalence. Rather than being torn between tribal loyalties and Colonial bravado, Minnehaha vacillates between the seductive temptress who "bends" and "draws" men and the obedient nymph who "obeys" and "follows."

Like the numerous revisions of Pocahontas in "Indian plays," Minnehaha represents an idealized image of conquered beauty and domesticated servant. Despite Hiawatha's initial protests that he prefers 
the beauty of a more natural "starlight" and "moonlight" to that of a "neighbor's homely daughter," his spiritual mentor, Nokomis, lectures him on the utility and necessary qualities of a proper wife: "Bring not here an idle maiden,/Bring not here a useless woman,/Hands unskilful, feet unwilling;/Bring a wife with nimble fingers" (Longfellow 179-80). Beneath the pen of Euro-American writers, the Native American character type came to embody the most romanticized desires of the patriarchal imagination. The creation of Hiawatha and Minnehaha as representatives of a gendered division-where male and female differences came to override the racial concerns of the previous eras-exemplifies the ways in which Native Americans, nonetheless, continued to serve as phantasmatic projections of the culture's most entrenched desires. Capitalizing upon the sedimented conceptions of the brave's fierce militarism and the Indian princess's exotic surrender, Longfellow's poetic narrative catapulted the material of myth to the level of literary truth.

Such an accomplishment allowed Hiawatha to seemingly reverse and rewrite the denigrated myth of the savage. Instead of drawing upon the entrenched history of the "savage," Longfellow casts his Native protagonist into an openly heroic model. Such a portrait presented the unjustly colonized and decimated Indian as a symbol of pending cultural collapse and a national loss of innocence. In the midst of the struggle to come to grips with the country's colonial heritage (one that depended upon the genocide of indigenous peoples and the enslavement of Africans as an exploitable labor pool), the portrait of Hiawatha came to stand for a more "universal" series of symbols and symptoms. As the "Black-Robe, chief, the Paleface," arrives in birch bark canoes to bring the message of Catholicism to the "generous Hiawatha," the poem documents a heroic denouement of epic proportions. As the "people from the margin" watch the protagonist's fragile craft sail out to its certain doom, the poem mythologizes Hiawatha's "westward" trajectory into a "sea of splendor." Thus, the future extinction of Native American culture in Longfellow's version arrives in the wake of the European missionary who, according to the dying Hiawatha, speaks "the truth...,/For the Master of Life has sent them/From the land of light and morning!" (Longfellow 265). Yet, while the irony of this exchange does not escape the writer or the reader, Longfellow concludes his poem by sending "Hiawatha the Beloved" into "the glory of the sunset" where he will be reborn in the afterworld of the poet's literary memorial. In this sense, the death of Hiawatha gestures toward a kind of poetic determinism where cultures ingest each other with no more lethality than generational shifts. For the country shorn of its indigenous inhabitants will be reborn in the inevitable ebb and flow of cultural usurpation and exchange. 
With the invention of tools such as the Sequoyah Script in 1821 and the push to document the life stories of infamous Indians during the nineteenth century by missionaries and historians, ${ }^{9}$ Native American perspectives began to make their way into the written record of U.S. history. Not surprisingly, these voices openly challenged the binary divide of the hero and savage by examining the 400 -year-old legacy of broken treaties and genocidal indifference. Oral addresses such as that delivered by Chief Joseph to government officials in Washington, D.C., in 1879, underscore the power of Indian orators as they grappled with the meanings of the western migration. After being secluded with his tribe on a plot of infertile land in the state of Washington, the Nez Percé spokesman spent the rest of his life attempting to convince the U.S. government and military representatives to honor the terms of treaties and the sovereignty of Native peoples.

In order to contest and revitalize cultural portraits of the Native American in Euro-American letters, Joseph's speech begins with a forthright challenge to the simplistic caricature of his people:

My friends, I have been asked to show you my heart. I am glad to have a chance to do so. I want the white people to understand my people. Some of you think an Indian is like a wild animal. This is a great mistake... I will tell you in my way how the Indian sees things. The white man has more words to tell you how they look to him, but it does not require many words to speak the truth. (19)

Such an introduction to Indian perspectives demonstrates the necessity of exposing the reductive logic of the savage in Euro-American letters. For Joseph, the struggle to revise a history of "lies" and false representations begins with a direct redress of a cumulative rhetorical history. In order to clear a space for his revisionary history to follow, the speaker strategically exposes the raw contours of the Indian as a mythical symptom of a national fantasy. In doing so, he prepares the way for a more humane and complex prototype of Native American character.

For Joseph, the Indian perspective arrives on the doorstep of the national capitol in the guise of a strategic revision and inversion. Rather than answer the "mystery" that the Indian represents for the white man, the speech adopts the rhetorical weapons of the colonizer by commenting upon what the Native cannot fathom about their white cohabitors:

But there are some things I want to know which no one seems able to explain. I cannot understand how the government sends a man out to fight us, as it did General Miles, and then breaks his word. Such a government has something wrong with it. 
I cannot understand why so many chiefs are allowed to talk so many different ways, and promise so many different things, I have seen this Great Father Chief (president), the next Great Chief (secretary of the interior), the Commissioner Chief (Hayt), the Law Chief (General Butler), and they all say they are my friends, and that I shall have justice. But while their mouths all talk right I do not understand why nothing has been done for my people. (57-58)

In this portrait, militia leaders and heads of state occupy the territory of mystery that had been so long occupied by the Indian as savage. The officials who "talk right" but refuse to turn promises into actions highlight the distance that exists between words and deeds in the discourse that addresses the "Indian problem." Joseph's strategic inquisition of the reigning authorities temporarily reverses the positions of power by inserting the Indian as the interlocutor of the government's mysterious actions. Consequently, Chief Joseph interrupts a 400 -year-old paradigm of Colonial explanation and helps to inaugurate a new era of revisions by Native American writers, orators and artists.

It would be these rhetorical tactics of inversion that became a cornerstone of Native American histories and fictions, and also provided the groundwork for the central trope of the trickster figure in contemporary Indian literature. While Native American speeches sought to expose the crude binaries of Euro-American mythos, Native American artists began to explicitly refashion the material of these myths into a viable literature of their own. Whereas Chief Joseph offers up a real world equivalent of the Indian to his white listeners, artistic appropriations of the hero/ savage divide embraced parodic forms that commented upon the ironies of contemporary Native American existence and the fallacy of Colonial truths. Caught in the "nowhere" of the legacy of Colonial definitions, Native writers created fictional characters who satirized (often in the most dire terms) the impossibilities of living as a captive audience in one's own ancestral lands.

In the remainder of this article we will look at several examples of the Native artist's response to the Indian as a symbolic product of nationalist myth. Perhaps the most innovative tool developed by this new generation of respondents is that of the trickster. Drawn from the rich folklore of Native cultures and honed to the needs of the contemporary Native artist, the characteristics of the trickster figure have proven adept at upending the mythic definitions of the Native as the harbor of EuroAmerican fantasies. While the function of the trickster figure is varied and complex, its primary role is to refute the binary simplicity of the savage-brave dichotomy. Unlike the singular "savage" in Colonial narratives, the Native trickster dons the armor of multiplicity-its apparition- 
like qualities allow a fluid characterization of tribal cultures that escape and evade the truthful pretensions of a racialized discourse.

Conventional analyses of the trickster figure in literary criticism tend to distinguish between two common characteristics: the transformer who unintentionally upsets the stagnant symbol of the Indian, or the cultural hero who consciously aids the creatures of the earth in their pursuit of survival. One quintessential example of this first trickster type occurs in David Seal's Powow Highway. In this episodic story that takes its narrative models from Kerouac's On the Road and Cheyenne oral traditions, the clumsy pursuit of the protagonist, Philbert Bono, inadvertently creates a heroic farce out of meaning, tradition and love. While Philbert comes across as meek and shy, he nonetheless intimidates Santa $\mathrm{Fe}$ lawmen with his cumbrous size (he's described as possessing Falstaffian physical proportions) and tricks his jailers out of their money and their prisoner.

Such a subversion of American institutional integrity proves emblematic of Native novelists who transform the most unlikely fictional characters into unwitting racial nemeses. Seals also subverts other prototypical popular heroes such as the Lone Ranger and his ethnic sidekick, Tonto, by offering the reader two "leads" who are given equal weight in the novel. Both Philbert Bono and Buddy Redbird, the heroes of Powow Highway, are contemporary Cheyenne survivors who face the continuing injustices of white culture but react to it in strikingly different ways. While Bono performs a spiritual quest guided by visions and ancient prophesies that come to him through dreams, meditations, and the $\mathrm{CB}$ radio, Redbird endeavors to rescue his sister while reacting with all of the violence of an action hero. As a result, Buddy's actions often create the comic out of the heroic, whereas Philbert's actions create the heroic out of the comic. Such a detailing of the distinctions between their reactions to the various episodes throughout the story provides a glimpse into the complexities of Native character, as well as the balance and humor of contrasting types.

In direct opposition to the stern forecasts of the meanings of Native barbarity in colonial narratives, the droll tone of Powow Highway accentuates one common device of the trickster novel. As the ironic narrator of the novel comments on the contemporary denizens of Pine Ridge, his language satirizes the heroic clichés of the dominant literary tradition within which the novel functions: "The 'bros' of the Sioux Nation fought off defeat and despair with the best weapon any nation had ever had for fighting off Defeat and Despair-they laughed in its face.... Tote that barge, shatter them myths, it's the only way out of slavery, brother!" (138-39). David Seals's trickster figures, including the narrator, portray 
the antiromantic, underside of American culture. The novel's appeal attempts to capitalize upon the farcical escapades of its characters while simultaneously highlighting the deadening myths of Native existence that must come crashing unceremoniously to the ground.

The second trickster-type - that of the beneficent cultural hero who aids the creatures of the earth to survive-appears in Leslie Silko's novel Ceremony, in the guise of Betonie, the Navaho medicine man. When the novel's protagonist, Tayo, discovers that all of the government doctors and local healers have given up on repairing his war-shattered spirit, he tentatively turns to Betonie for help: "[W]hat good can Indian ceremonies do against the sickness that comes from their wars, their bombs, their lives?" (132). In response, the modern-day medicine man who believes that ancestral rituals must sometimes be changed because "long ago when people were given these ceremonies, the changing began" (126), Betonie explains Tayo's hopelessness and resentment as part of "the trickery of witchcraft."

They want us to believe that all evil resides with white people. Then we will look no further to see what is really happening. They want us to separate ourselves from white people, to be ignorant and helpless as we watch our destruction. But white people are only the tools that the witchery manipulates; and I tell you, we can deal with white people, with their machines and their beliefs. We can because...it was Indian witchery that made white people in the first place. (132)

Betonie's explanation reverses the very terms of creation itself by making Euro-American settlers an invention of Indian lore. The "witchery" that he describes suggests that, in Native narrative, whites occupy the position of symbolic corruption. Betonie (like Chief Joseph before him) acts as a reflective mirror that inverts the racial equation of early American writers. In Betonie's view, "whites" act in the world not by any personal volition but rather as the manipulated objects of larger forces.

After Betonie's ceremony in the center of the novel, Tayo slowly begins to transform from his previously apathetic self to a moral actor of heroic proportions. At the end of the novel he saves himself from being drawn into the forces of destruction by turning away from the cultural imperative to violence, tricking the witchery and entering the kiva to tell his story. Accordingly, the nonsavage trickster becomes storyteller, thereby keeping alternative stories alive to save the culture and his newly reclaimed people.

In Paul Radin's extensive study of the traditional Winnebago trickster, he delineates the roles of the trickster as a "creator, a destroyer, and 
an apparently, amoral being consumed by his own appetites...through [whose] actions all values come into being" (xxii). In James Welch's surrealistic novel, Winter in the Blood, the unnamed narrator, an unlikely hero, opens the narrative by awakening in a ditch with a hangover. A survivor of historical, tribal, familial, and cultural trauma, he has to battle his own psychological ghosts, an Oedipal complex and the Colonial American images of Randolph Scott and drunken Indians. "But," he tells the reader, "the distance I felt came not from the country or people; it came from within me" (2).

The narrator of Winter in the Blood does not succeed in his quest to find his Cree girlfriend and bring her home, but his search for identity outside white stereotypes gives tribal life meaning in the novel. In a comic revelation, as Bird, his old horse, farts, the narrator discovers the historical and narrative significance of his grandmother's life. At the end of the narrative, he puts his grandmother's medicine pouch in her grave and bravely decides to go back and find his girlfriend. These gestures against Colonial representations of the Native as "savage" restore the power of Native traditions and continue a vital struggle for cultural and individual survival.

The struggle to save a Native woman from both an antagonistic tribe and the seductions of movie magazine images proves worthy of a trickster who bears memories of traditional culture as well as originates value in a new and complex world. An alternative value is created in the novel through the rejection of Colonial heroes, sex symbols, and stereotypes. A story that begins in winter, ends in cleansing spring rain.

Many of Louise Erdrich's Ojibwa characters take on larger-than-life heroic qualities, and by their very excessive natures and violations of social restrictions become heroic tricksters themselves. The character Gerry Nanapush of Love Medicine, emblematic of the mythic trickster in name and character, significantly revises the savage-hero archetype. Gerry fathers a clairvoyant son who explains the trickster-like nature of his heroic figure:

No concrete shitbarn prison's built that can hold a Chippewa, I thought. And I realized instantly that was a direct, locally known quote of father, Gerry Nanapush, famous politicking hero, dangerous armed criminal, judo expert, escape artist, charismatic member of the American Indian Movement, and smoker of many pipes of kinnikinnick in the most radical groups. That was...Dad. (248)

In contrast to these multicultural skills of judo expert and escape artist, Gerry must be portrayed by the authorities as the "savage" in 
order to quiet political activism. However, in order to pursue his goals to live, love, and enjoy life, Gerry must be in constant confrontation with the social-political restrictions of the cultural authorities that be.

After the jail break, Lipsha narrates an emblematic scene in which he and Gerry play poker with Lucky Charms cereal marshmallows against King, the apple Indian, "red on the outside, white on the inside" (259). However, the heroes have the advantage of "[a] marked deck. For the marked man, which was all of us. I was marked for pursuit by authority as was my father, but King was marked in an entirely different way" (259). The poker game parodies the traditional Ojibwa myth of the trickster, Nanabozho, playing the role of the evil gambler in that the object of the game in both is the same: to escape and to free the people, a matter of life and death.

The heroic function of the trickster who creatively intervenes in lifeand-death matters continues to provide an important model of cultural power in Native American texts. Alanis Obomsawin's 1993 documentary film, Kanehsatake: 270 Years of Resistance, details the struggles of Mohawk warriors endeavoring to preserve ancestral lands from the dictates of city and national governments. As the Canadian military gradually surrounds a small enclave of protesters who "were never more than 30 warriors...one spiritual leader, one traditional chief, 19 women and 7 seven children," with miles of razor wire, tanks and heavily armed soldiers, the film chronicles a contemporary replay of colonial dynamics. During one postprotest interview with Native activist, Donald Hemlock who was arrested and beaten during the final clash, the laugh of the trickster meets up with the historic refusal of Native peoples to speak their surrender and subjugation: "He (one of the military soldiers) banged my head on the road. But I would just laugh and say stuff. 'Give up. You've lost now,' [he said]. 'We didn't lose.' Then I started to struggle harder and more men jumped on me to hold me down."

The government soldier's attempt to extract an admission of surrender from Hemlock, spurs him on to "struggle harder," and represents the 270-year-old legacy to which Obomsawin's subtitle alludes. His retort of "[W]e didn't lose" echoes with the historical reverberations of the Aztec's original refusal. In the clash of culturally laden symbolic systems, the power to "recognize" and outmaneuver definitions imposed from without surfaces as the supreme act of political resistance and a necessary act of communal integrity.

Prior to this commentary, one member of the resistance movement sounds a triumphant note when he exclaims, "We tricked them." Another participant in the resistance effort comments, "[W]e never did the expected thing, it was always the unexpected." The numerous instances 
of Native trickery on display in Kanehsatake suggests a key continuity between the devices of literary fictions and the tactics of cultural survival. The significance and function of the trickster cannot be underestimated as a counternarrative strategy of contemporary Native culture. The open rejection of the Euro-American paradigm of the hero-savage dichotomy survives in the trickster's symbolic tactics of appropriation and resistance. Such activities serve as a literary hall of mirrors perpetually reflecting the dehumanizing coordinates of the "Indian" back upon its originators. In doing so, the words and literature of Native Americans serve as a disruptively productive force within the realm of American letters. The trickster's cathartic laugh proves both defiant and restorative. His figure has set a new kind of American hero on the literary horizonone that insists upon the revitalizing possibilities of imaginative language for the necessity of cultural survival.

\section{Notes}

'This specific analysis of the ambivalence that informs the text of cannibalism in travel literature of the New World is recognized by Montaigne in his sixteenth century essay entitled "Of Cannibals." The "savage" in his analysis represents the ambiguous projection of a European binary that locates an us/them split, and consequently, alienates the "perceiving" culture from achieving any humane intimacy with the "foreign" culture. For an even more expanded version of this argument see Michel deCerteau's analysis of Montaigne's essay "The Savage 'I'," in Heterologies: Discourse of the Other.

${ }^{2}$ Inga Clendinnen has explored this facet of colonial relations with a great deal of insight. In a recent essay entitled, "Fierce and Unnatural Cruelty," she also examines the ways in which historians and philosophers have perpetuated this colonial impasse through arguments that posit Aztec peoples as dupes of their own "literality." Rather than analyzing the collision of cultures and the alarming ferocity of Spanish warfare, historians of Central American colonization have insisted that the Conquistadors were mistaken by a more primitive culture as being the prophesied gods of their own mythic histories. Such an analysis, argues Clendinnen, continues to position Native peoples as the less sophisticated "other" to the European mastery of signs.

'David Brion Davis' seminal study The Problem of Slavery in Western Civilization, illuminates the necessity of going to Africa for slaves rather than subjugating more accessible indigenous peoples. Frederick Douglass's slave narrative, The Narrative of the Life of Frederick Douglass, also details the key refusal of slave-holding society to educate slaves in order to foster and continue this key strategy of alienation and dislocation. 
"In Columbus's "Letter to the Sovereigns" he describes the Native peoples on the island of Hispanola as the "best people under the sun" and three paragraphs later predicts "the taking of the Indies and all they contain" with an army of "fifty thousand foot soldiers" $(4,7)$.

${ }^{5}$ The Puritans consistently explained Native American behavior in New England in terms of their utility to God (and their Puritan ministry) as punitive instruments. In order to better control their congregations, the religious authorities played upon the populace's fears of what lay beyond the settlement's boundaries by describing the Indians as "creatures of the Devil" and "merciless savadges." For instance, Increase Mather's history of King Phillip's War underscores the barbarous nature of this opposition by persistently connecting the Indians with images of hell and as symbols of God's wrath. The Puritan Jeremiad would ruthlessly exploit such rhetoric as the formulaic foundation of New England ideology, and for more than one hundred years the Indian functioned in the religious literature of the country not as a people but as the evidentiary tools of salvation or damnation.

${ }^{6}$ Among the numerous examples of Native American antagonisms that fueled various coalitions with European colonizers are those mentioned in Diaz's history and the early New England wars. In the case of the former, the Spaniards successfully complete their trek to Tenochtitlan by adeptly anticipating and manipulating tribal factionalism. The Aztec empire was maintained by a hierarchical series of networks where stronger military tribes (supported by the arms and militia of Moctequma) preyed upon the riches and enslavement of weaker communities in the outlying areas. As Cortes maneuvered his men across the continent, he promised to protect these subjected populations in exchange for their loyalty to the Spanish crown and troops to fortify his own diminishing ranks.

In New England, where the relationships between European immigrants and local Native clans were based largely upon trade, the situation proved to be less military for the first five decades for the Colonial mission. Yet, during the Pequot and King Phillip's Wars, Colonial militias counted upon their tribal trading partners to help quell Native American uprisings against their expansionist designs. William Bradford, in his History of Plymouth Plantation, details the participation of Puritan forces in the brutal slaughter of one Pequot tribe by the rival Narragansetts, and they in turn refused to participate in the attack on Puritan settlements during the largely successful campaign of Metacom (dubbed "King Phillip" by the colonists).

${ }^{7}$ All of the figures on the length and evolution of the Pocahontas myth in Smith's narrative come from J. A. Leo Lemay's study entitled Did Pocahontas Really Save Captain John Smith?

${ }^{8}$ Although the love interest in Dances with Wolves is a white woman adopted by Native Americans, the movie endeavors to play off of the erotic 
potential of cultural crossings. Since her character has lived as an Indian all her life, she still capitalizes on the Indian princess myth of Pocahontas. Because the film has to go to such lengths to "find" a suitable "Native" spouse for its American male lead, one is left wondering why such a romantic subplot could not have been a bona fide Native woman herself.

${ }^{9} \mathrm{~A}$ discussion of the significance of the invention of the Sequoyah Script occurs in Ronald Wright's Stolen Continents. The tool allowed for the translation of several Native languages into English, and consequently a written record of Native perspectives could be recorded in the print archives of American letters and histories. Among those stories preserved during the nineteenth centuries were the political speeches of Native men such as Chief Joseph, Chief Red Jacket, and Chief Seattle, and the autobiographies of Native women such as Sacajawea, Sarah Winnemucca, and Mountain Wolf Woman.

\section{Works Cited}

Bradford, William. History of Plymouth Plantation, 1620-1649. New York: Modern Library College Editions, 1981.

Clendinnen, Inga. " 'Fierce and Unnatural Cruelty': Cortes and the Conquest of

Mexico." New World Encounters. Ed. Stephen Greenblatt. Berkeley: U of California P, 1993. 12-47.

Columbus, Christopher. "Letter to the Sovereigns." New World Encounters. Trans. Margarita Zamora. Ed. Stephen Greenblatt. Berkeley: U of California P, 1993. 1-11.

deCerteau, Michel. "Montaigne's 'Of Cannibals': The Savage 'I'."

Heterologies: Discourse of the Other. Minneapolis: U of Minnesota P, 1986.

Diaz, Bernal. The Conquest of New Spain. New York: Penguin, 1963.

Erdrich, Louise. Love Medicine. New York: Holt, 1984.

Kenehsatake: 270 Years of Resistance. Dir. Alanis Obomsawin. Oley, PA: Bullfrog Films, 1993.

Lemay, J. A. Leo. Did Pocahantas Save Captain John Smith? Athens: U of Georgia P, 1992.

Longfellow, Henry W. Hiawatha. The Poems of Henry Wadsworth Longfellow. New York: Modern Library, 1955.

Mather, Increase. "A Brief History of the War with the Indians in New England." So Dreadfull a Judgment: Puritan Responses to King Philip's War, 1676-1677. Ed. Richard Slotkin and James K. Folsom. Middletown, CT: Wesleyan UP, 1978. 55-206.

Montaigne, Michel. "Of Cannibals." The Complete Essays of Montaigne. Stanford: Stanford UP, 1958. 
Radin, Paul, ed. The Trickster: A Study in American Indian Mythology. New York: Schocken, 1972.

Rowlandson, Mary. "Narrative of the Captivity and Restoration of Mrs. Mary Rowlandson." So Dreadfull a Judgement. Ed. Richard Slotkin. Middletown, CT: Wesleyan UP, 1978. 301-69.

Seals, David. Powow Highway. New York: Dutton, 1990.

Silko, Leslie Marmon. Ceremony. New York: Viking, 1977.

Smith, Captain John. The Generall Historie of Virginia. Murfreesboro, NC: Johnson, 1642.

Vizenor, Gerald. "Trickster Discourse: Comic Holotropes and Language Games." Narrative Chance: Postmodern Discourse on Native American Literatures. Ed. Gerald Vizenor. Alberquerque: U of New Mexico P, 1989.

Welch, James. Winter in the Blood. New York: Harper, 1974.

David T. Mitchell is an associate professor of English at Northern Michigan University where he teaches American literature. Currently he serves as the president of the Society for Disability Studies and as the series editor for "Corporealities: Discourses of Disability" (U of Michigan P). He is also the coeditor of the recent collection entitled The Body and Physical Difference (Ann Arbor: U of Michigan P, 1997).

Melissa Hearn is an associate professor of English at Northern Michigan University where she teaches Native American Literature. 